\title{
ОСОБЛИВОСТІ СИМУЛЯЦИЙНОГО НАВЧАННЯ ПРИ ВИВЧЕННІ ПЕДІАТРИЧНИХ ДИСЦИПЛІН
}

\author{
О. Р. Боярчук, І. Б. Чорномидз, Т. О. Воронцова, М. І. Кінаш \\ ДВНЗ “Тернопільський державний медичний університет імені I. Я. Горбачевського \\ МОЗ України”

\section{PECULIARITIES OF SIMULATION TEACHING OF PEDIATRIC DISCIPLINES} \\ O. R. Boyarchuk, I. B. Chornomydz, T. O. Vorontsova, M. I. Kinash \\ I. Horbachevsky Ternopil State Medical University
}

\begin{abstract}
У статті викладено досвід проведення занять з педіатрії у симуляційному центрі Тернопільського державного медичного університету імені І. Я. Горбачевського. Проаналізовано основні переваги симуляційного навчання, та висвітлено методики викладання занять 3 педіатрії, а зокрема пропедевтичної педіатрії, догляду за хворими та сестринської практики, використовуючи технічні можливості симуляційного центру університету.
\end{abstract}

The article presents the experience of lessons on Pediatry in simulation center of I. Horbachevsky Ternopil State Medical University. The basic advantages of simulation training, and covers methods of teaching classes in pediatrics, particularly propaedeutic pediatrics, nursing and nursing practice, using the technical capabilities of simulation center university are studied.

Вступ. Досить високий рівень теоретичної підготовки у вищих медичних навчальних закладах і низький рівень володіння студентами практичними навичками майбутньої професії диктує вимоги нових освітніх стандартів до професійної компетенції випускників та необхідність змін у методології медичної освіти в об’єктивних умовах реальної практики в охороні здоров’ я [4].

Застосування сучасних технологій освоєння i вдосконалення практичних навичок у фаховій підготовці медичних працівників є важливою умовою для забезпечення їх якісної професійної компетенції. Симуляційне навчання в Україні поступово стає невід’ємною частиною діяльності медичних вузів і організацій охорони здоров’я, що знаходить своє відображення в державних програмах розвитку охорони здоров’я та медичної освіти $[1,2]$.

Проблемами при проходженні клінічних дисциплін є відсутність індивідуального забезпечення студентів тематичними хворими, вимушеною роботою в групі, і тим більше проблематичним є повний контроль викладача за якістю виконання кожним студентом об’єктивного обстеження пацієнта. Серед факторів, які сприяють погіршенню ситуації,

(c) О. Р. Боярчук, І. Б. Чорномидз, Т. О. Воронцова, М. І. Кінаш
$€$ збільшення кількості студентів у групі з кожним роком, зниження кількості хворих, госпіталізованих у стаціонар, з одночасною зміною контингенту хворих з переважанням тяжкохворих дітей, негативізм батьків хворих дітей по відношенню до медичних працівників, у тому числі і студентів, що пов'язано з економічними та соціальними проблемами. Все це впливає на погіршення комунікативного процесу між тематичним хворим і медичним працівником, відпрацювання практичних навичок та обстеження пацієнта [4].

Саме цей вид підготовки студентів медичних факультетів є найбільш перспективним та має свої переваги, а саме:

1. Клінічний досвід без ризику для пацієнта.

2. Можливість створення клінічних ситуацій, максимально наближених до реальних.

3. Відпрацювання та підтримка набутих вмінь 3 відпрацювання практичних навичок.

4. Об’єктивна оцінка досягнутого рівня майстерності.

5. Відпрацювання взаємодій при командній роботі.

6. Не однократність повторів дій для формування належних вмінь та ліквідації помилок.

7. Тренінг у зручний час. 
8. Відпрацювання дій при рідкісних патологіях.

9. Частину функцій викладача бере на себе віртуальний тренажер.

10. Зниження стресу при перших самостійних маніпуляціях [3].

Основна частина. На базі симуляційного центру Тернопільського державного медичного університету проводяться заняття з догляду за педіатричними хворими та пропедевтичної педіатрії. Кабінет симуляційного навчання в педіатрії відтворює фрагменти палати педіатричного відділення із доглядом за дітьми різного віку та їх фізикального обстеження [6]. Серед чисельного устаткування симуляційного центру особливе місце посідає студентський манекен для аускультації, який надає можливість повторення навичок об'єктивного обстеження пацієнта в нормі та патології, зокрема аускультації легень. Даний симулятор дозволяє змінювати окремі параметри при вивченні різних станів, що допомагає студентам опанувати необхідні навички і наближає їх до умов реальної клінічної практики.

Під час викладання педіатрії на молодших курсах університету (пропедевтика та догляд за дітьми) нами використовуються такі види навчань, які можливо проводити на базі симуляційного центру:

1. Індивідуальні тренінги на манекенах та фантомах (проведення практичних занять, де студенти під керівництвом викладача самостійно відпрацьовують навички об'єктивного обстеження дитини та оцінки її антропометричних даних, елементи догляду за дітьми).

2. Моделювання ситуаційних задач (багатоступеневі ситуації, коли студент відпрацьовує практичні навички за стандартними алгоритмами).

3. Командне відпрацювання навичок при клінічних ситуаціях (у такому випадку студенти навчаються злагодженої роботи в команді).

Орієнтуючись на вже наявний досвід викладання, на нашій кафедрі використовуються різні активні методи навчання: метод активного діалогу (дискусія), презентація, бригадно-рольовой метод, симуляційні рольові ігри. Під час симуляції нами оцінюються: 1) комунікативні (етичні) навички майбутнього фахівця; 2) професійні знання (збір анамнезу, інтерпретація даних об'єктивного обстеження, визначення основних клінічних синдромів, правильне проведення елементів догляду за дітьми різного віку та лікарських маніпуляцій); 3) спеціальні навички (зокрема аускультація легень і т. п.).

При завершенні заняття в ході психологічного дебрифінгу відбувається детальний аналіз та оцінка роботи студентів, розробляється єдиний алгоритм дій згідно з клінічними стандартами.

Отже, при симуляційному навчанні враховуються всі три аспекти класифікації Блума з оцінки цільових навчальних компетенцій:

- когнітивні завдання навчання (знання) - “Що учасники програми мають знати?”;

- психомоторні завдання навчання (вміння) - “Що учасники зобов’язані вміти робити?”;

- афективні завдання навчання (поведінка) - “Про що учасники повинні думати або піклуватись?” $[1,2]$.

Висновок. Таким чином, перевагами симуляційних методів навчання є: формування навичок практичного досвіду майбутніх спеціалістів без нанесення шкоди здоров'ю пацієнта при відпрацюванні маніпуляцій на муляжах і симуляторах; глибоке засвоєння матеріалу; формування загальної і професійної компетенції, необхідної для здійснення практичної діяльності завдяки створеним імітаційним умовам професійного середовища, що дозволяє вважати їх ефективними для формування практичної компетентності студентів. Інтерактивне навчання сприяє формуванню навичок і вмінь, атмосфери співробітництва, взаємодії, дає педагогу змогу стати авторитетним наставником студентського колективу. Студенти вчаться толерантно спілкуватися між собою та викладачем, критично мислити, приймати рішення. Використання симуляційних технологій підвищує інтерес до процесу навчання і $€$ важливою частиною у підвищенні професійної компетенції лікарів.

2. Створення симуляційного центру: засади та керівні настанови. Досвід Програми “Здоров’я матері та дитини” : посібник. - К. : Вістка, 2015. - 56 с.

3. Дорожня карта віртуальної клініки / М. Д. Бітчук, І. В. Завгородній, Д. П. Перцев, Ж. І. Логвінова // Симуляційне навчання в системі підготовки медичних ка- 
дрів : матеріали L навч.-метод. конф., присвяченої 212-й річниці від дня заснування (Харків, 30 листопада 2016 року). - Харків : ХНМУ, 2016. - С. 22-24.

4. Симуляційне навчання на кафедрі пропедевтики педіатрії № 2 / В. А. Клименко, Г. С. Сивопляс-Романова, Ю. В. Карпушенко [та ін.] // Симуляційне навчання в системі підготовки медичних кадрів: матеріали L навч.-метод. конф., присвяченої 212-й річниці від дня заснування (Харків, 30 листопада 2016 року). - Харків : ХНМУ, 2016. - С. 61-63.
5. Роль симуляційного навчання у процесі підготовки бакалавра та магістра медицини за фахом “Медсестринство” / Т. С. Оспанова, Т. В. Бездітко, М. В. Панченко [та iн.] // Симуляційне навчання в системі підготовки медичних кадрів : матеріали L навч.-метод. конф., присвяченої 212-й річниці від дня заснування (Харків, 30 листопада 2016 року). - Харків : ХНМУ, 2016. - С. 121-124.

6. Розвиток практично-орієнтованого та симуляційного навчання в Тернопільському державному медичному університеті імені І. Я. Горбачевського / М. М. Корда, А. Г. Шульгай, А. А. Гудима, С. Й. Запорожан // Медична освіта. - 2016. - № 2. - С. 54-57.

Отримано 07.11.16 